\title{
Kronik Obstrüktif Akciğer Hastalığı Olan Bireylerin Kronik Hastalık Yönetimine İlişkin Değerlendirmeleri ve İlişkili Faktörler*
}

\author{
Related Factors and Patient Assessment of Chronic Illness Care in Patients with \\ Chronic Obstructive Pulmonary Disease
}

\author{
Emine ÜSTÜNOVA**, Nursen NAHCIVAN***
}

İletişim/Correspondence: Nursen NAHCIVAN Adres/Adress: İstanbul Üniversitesi Florence Nightingale Hemşirelik Fakültesi, Abide-i Hürriyet Cad. 34381 Şişli/ İstanbul Tel: 0212-440 0000 (Dahili 27058) Fax: 0212-224 4990 E-mail: nursen@istanbul.edu.tr

\begin{abstract}
$\ddot{O} Z$
Amaç: Bu araştırmanın amacı, Kronik Obstrüktif Akciğer Hastalı̆̆l (KOAH) olan bireylerin kronik bakım yönetimlerini nasıl değerlendirdiklerini belirlemek ve kronik bakım yönetimlerinde iliskili olan faktörleri incelemektir.

Yöntem: Tanımlayıcı-kesitsel tipteki araştırmanın örneklemini, İstanbul'da üç Aile Sağllğı Merkezi ve iki hastaneden hastalı̆̆ı nedeniyle hizmet alan 300 KOAH hastası oluşturdu. Veriler Hasta Tanılama Formu ve Kronik Hastalık Bakımını Değerlendirme Ölçeği-Hasta Formu kullanılarak toplandl. Verilerin analizinde sayl, yüzde, ortalama, standart sapma, medyan, $t$-testi, ANOVA ve korelasyon analizi kullanıld . Bulgular: Yaş ortalaması $63.89 \pm 11.14$ (min-max= 38-87) olan örneklemin çoğunluğu erkek (\%70.3), evli (\%83), ilkokul mezunu (\%41.7) ve

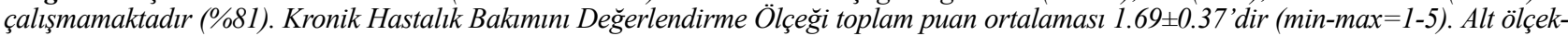

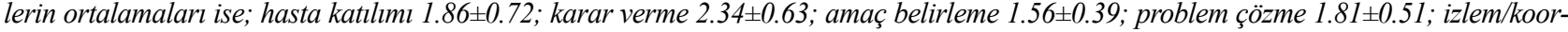
dinasyon 1.24 0.50 'dir. Yaş, cinsiyet, medeni durum, çalışma durumu, eșlik eden hastalık, sağlık hizmeti alınan süre, son altı ayda acile başvurma ve hastanede yatma durumu ile kronik hastalı yönetimine ilişkin memnuniyet puan ortalamaları arasındaki fark anlamlı bulunmazken; eğitim durumuna göre ve hastaneden hizmet alan ile hastalı̆̆ına ilişkin bilgi alan hastalarda kronik hastalık yönetimi memnuniyet puan ortalamaları arasındaki fark anlamlı bulundu. Ayrıca hastalarda hastalık süresi arttıkça, memnuniyet puan ortalamaları da artmaktadır.

Sonuç: KOAH'lı hastaların kronik bakım yönetimine ilişkin memnuniyetleri oldukça düşüktür. Hastalık yönetimini kapsayan hizmet süreçlerinde, "hasta katılımı, karar verme, amaç belirleme, problem çözme ve izlem/koordinasyon" alanlarındaki yetersizlikler hasta memnuniyetini azaltan başlıca nedenlerdir. KOAH'lı hastalara sunulan hastalık yönetimi hizmetlerinin planlanmasında kronik bakım modeli bileşenlerinin dikkate alınması hasta memnuniyetini artırabilir. Bu konuda KOAH'lı hastaları temsil eden örneklemlerde çallsilmasina ve ileri arastırmalar yapilmasina gereksim vardir.
\end{abstract}

Anahtar Kelimeler: Kronik Obstrüktif Akciğer Hastalı̆̆l (KOAH), kronik bakım yönetimi, PACIC, hemşirelik.

\section{ABSTRACT}

Aim: The purpose of this to determine perceive chronic care management and related factors of the people with Chronic Obstructive Pulmonary Disease (COPD).

Method: Sample of study which designed descriptive and cross-sectional consisted of 300 patients who treated in health care centers or hospitals in Istanbul. The data has been collected with Patient Identification Form and Patient Assessment of Chronic Illness CarePatient Form. Analysis of the data; number, percent, mean, standart deviation, median, $t$ test, ANOVA, correlation were used.

Results: Average age of sample group were $63.89 \pm 11.14$ (min-max=1-5), most of them were male (\%70.3), married (\%83), primary school graduated (\%41.7) and does not work (\%81). Average score of Patient Assessment of Chronic Illness Care is 1.69 \pm 0.37 (min-max=1-5). Average scores of subscales were; patient activation 1.86 \pm 0.72 , decision support $2.34 \pm 0.63$, goal setting $1.56 \pm 0.39$, problem-solving $1.81 \pm 0.51$, follow-up 1.24 \pm 0.50 . No statiscally significant difference was found with age, sex, marital status, operating state, chronic conditions, duration of treatment, status of visit emergency and duration of hospitalization. The satisfaction with chronic care management was higger in patients with educated, treated in hospital and informed about illness. Also average score of satisfaction increases if duration of disease increases. Conclusion: Findings revealed that patients with Chronic Obstructive Pulmonary Disease have low satisfaction about chronic care management. Deficiencies according to "patient activation, decision support, goal setting, problem solving and follow up" are mean reasons to reduce patient satisfaction. Results of the study is recommended in health programme and quality improvement study in patients with Chronic Obstructive Pulmonary Disease.

Key Words: Chronic Obstructive Pulmonary Disease (COPD), chronic care management, PACIC, nursing.

* İstanbul Üniversitesi Sağlk Bilimleri Enstitüsü Yüksek Lisans Tezi 2013, 16. Ulusal Halk Sağllğı Kongresi’nde sözel bildiri olarak sunulmuştur (27-31 Ekim 2013, Antalya), **Uzm. Hem. Acıbadem Atakent Hastanesi, Klinik Eğitim Hemşiresi, **Prof. Dr. Istanbul Üniversitesi Florence Nightingale Hemşirelik Fakültesi

Yazının gönderilme tarihi: 13.02 .2014

Yazının basım için kabul tarihi: 28.12.2014 


\section{GíRiş}

Kronik Obstrüktif Akciğer Hastalığı (KOAH), tüm dünyada en sık görülen hastalık ve ölüm nedenleri arasındadır ve tüm ülkeler için ciddi bir sağlık sorunu ve ekonomik yük oluşturmaktadır (GOLD 2006; WHO 2012). Türkiye Hastalık Yükü Çalışması verilerine göre, ülkemizdeki ölümlerin \%70'ini kronik hastalıklar oluşturmakta ve KOAH (\%6) ölüme sebep olan ilk on hastalık içinde üçüncü sırada yer almaktadır (Ünüvar, Mollahaliloğlu ve Yardım 2006). Yapılan çalışmalar KOAH'in günlük yaşam aktivitelerini olumsuz etkileyerek hastaların bağımlılık düzeylerini artırdığını göstermektedir (Aşti ve Kara 2002; GOLD 2006; Ünsal ve Yetkin 2005).

Aynı zamanda KOAH'ın sebep olduğu sakatlıklar, iş gücü kayıpları ve sağlık harcamaları dolayısıyla, toplumlar için oluşturduğu sosyoekonomik yük de giderek artmaktadır. Küresel bir sağlık sorunu olduğunun daha iyi anlaşılması ile son yıllarda hastalığa olan ilgi artmıştır (Tatlıcıoğlu 2007). Bu sebeple diğer kronik hastalıklarda olduğu gibi KOAH'da da hastalık kontrolü ve toplum temelli hastalık yönetim programlar1nın önemi giderek artmaktadır (Adams ve ark. 2007). Kronik hastalık yönetimi hastalığın tedavisinden çok, hastanın, öz-yönetim becerisi kazanması için çeşitli öğretim yöntemleriyle hazırlanması ve güçlendirilmesi olarak tanımlanmaktadır (Bourbeau ve Palen 2009; İncirkuş ve Nahcivan 2011). İyi bir hastalık yönetimi acil servise başvuruları ve hastaneye yatışları azaltma11 bunun yanında hastanın fiziksel ve mental fonksiyonlarında iyileşme sağlamalıdır (Hasket 2006).

Hemşireler, KOAH için yürütülen kronik hastalık yönetiminde kilit sağlık profesyonelleridir (Taylor ve ark. 2005). Nitekim Uluslararası Hemşireler Birliği (ICN), hemşirelerin kronik hastalık yönetiminde lider rolde olduklarını vurgulamaktadır (ICN 2010). Hemşireler tarafından yürütülen hastalık yönetimi çalışmalarında genel olarak; hastaneye/acile yatış sayısı, sağlık harcamaları, yaşam kalitesi, hasta bilgi düzeyi gibi verilerde olumlu sonuçlar görülmüştür (Bourbeau ve ark. 2003; Casas ve ark. 2006; Fernandes, Pache, Bird ve Bryden
2006; Hermiz ve ark. 2002; Jonsdottir 2007). ICN'nin 2010 yılında yayınladığı raporunda, çeşitli ülkelerde kronik hastalıkların bakımı için çeşitli modellerin kullanıldığı belirtilmektedir. Kronik hastalık yönetimi için en çok kullanılan, en iyi bilinen ve en etkili olan model, Kronik Bakım Modeli'dir. (Escarrabill 2009; İncirkuş 2010; İncirkuş ve Nahcivan 2011). Model, hastalık yönetiminde önemli öğelerden sağllk bakım organizasyonu, sağlık bilgi sistemleri, sağllk hizmetleri sunum plant, karar verme desteği, öz-yönetim desteği ile toplum kaynaklart ve politikalara odaklıdır (Adams ve ark. 2007; Aragones ve ark. 2008; Glasgow ve ark. 2005b; İncirkuş 2010; Rosemann, Laux, Droesemeyer, Gensichen ve Szecsenyi 2007). Aynı zamanda modelde tanımlanan bu ögelerin yanı sıra kronik hastalık yönetiminde hasta memnuniniyeti ile ilişkili olabilecek çeşitli etmenlerin de önemi vurgulanmaktadır. Nitekim çeşitli çalışma raporlarında hastaların kronik hastalık yönetimine ilişkin değerlendirmelerinde yaş, cinsiyet, medeni durum, eğitim, çalışma durumu (Aragones ve ark. 2008; Glasgow ve ark. 2005b; İncirkuş 2010); hastalık süresi, eşlik eden hastalı, hastanede yatma ve acile başvurma durumu (Aragones ve ark. 2008; Aydın, Yıldız, Karagözoğlu ve Özden 2012; İncirkuş 2010) ve hastalığa yönelik bilgi alma durumu ile bilgi kaynakla$r l$ (İncirkuş 2010; Sayıner ve ark. 2012) gibi birçok değişkenin önemli olabileceği vurgulanmaktadır.

Çeşitli çalışmalarda Kronik Bakım Modeli'nin diyabet, kalp hastalıkları, depresyon, astım gibi hastalıklarda kullanıldığı ve bu hastalık gruplarında sağlık harcamaları ile acile/hastaneye başvuruları azalttı̆̆ 1 , yaşam kalitesi ve hasta memnuniyetini ise yükselttiği belirtilmiştir (Aragones ve ark. 2008; Glasgow, Nelson, Whitesides ve King 2005a; Glasgow ve ark. 2005b; Rosemann ve ark. 2007; Wensing, Lieshoud, Jung, Hermsen ve Rosemann 2008). Ancak KOAH'lı bireylerin hastalık yönetimlerini Kronik Bakım Modeli'ne göre inceleyen çalışmalar oldukça azdır. KOAH'lı hastalarda kronik bakım modelini temel alarak yapılan iki çalışmada (Adams ve ark. 2007; Bodenheimer, Wagner ve Grumbach 2002) modelin öğelerinin uygulanmasıyla hastalarda acile başvuru oranı, hastaneye ya- 
tış sıklığı ve hastanede kalma süresinin azaldığı gösterilmiştir. Türkiye'de KOAH'ın hastalık yükünü sürekli izleyen ve sağlıklı veri toplayan bir sistem bulunmamakla beraber Sağlık Bakanlığınca oluşturulan "kronik havayolu hastalıklarını önleme ve kontrol progra$m \imath$ " ile Türkiye'de bu hastalıklara bağlı ölümlerin ve beraberinde getirdiği ekonomik yükün azaltılması hedeflenmektedir (T.C. Sağlık Bakanlığg 2009). Bireylerin yaşamını birçok açıdan olumsuz yönde etkileyen önemli bir kronik hastalık olmasına karşın KOAH'ın, yaşamlarını nasıl etkilediğini hastaların bakış açısıyla inceleyen çalışmalar ülkemizde sınırlıdır (Aydın ve ark. 2012). Bu nedenle KOAH'lı hastaların kendi bakış açılarından aldıkları kronik bakım hizmetlerini nasıl algıladıklarını değerlendirmek ve hastalık yönetiminden memnuniyetleri ile ilişkili olan etmenleri incelemek önemlidir. Bu bağlamda çalışmanın amacı, KOAH'lı hastaların kronik bakım yönetimlerini nasıl değerlendirdiklerini belirlemek ve kronik bakım yönetimde ilişkili olan faktörleri incelemektir. Araştırma sonucunda elde edilen verilerin KOAH'l1 hastalara verilen bakımın kalitesini artırmaya yönelik hastalık yönetimi programlarının yapılandırılmasında yol gösterici olacağ 1 düşünülmektedir. Araştırma kapsamında yanıt aranan başlıca araştırma soruları şunlardı:

- KOAH'lı hastaların kronik hastalık yönetimine ilişkin değerlendirmeleri nasıldır?

- KOAH'lı hastaların kronik bakım yönetimine ilişkin memnuniyet puan ortalamaları nedir?

- KOAH'lı hastaların kronik bakım yönetimine ilişkin memnuniyet puan ortalamaları ile bazı sosyodemografik değişkenler, hastalık ve sağlık hizmet özellikleri arasında anlamlı ilişki var mıdır?

\section{YÖNTEM}

Araştırmanın Tipi, Yeri ve Örneklemi: Tanımlay1c1 ve kesitsel tipte planlanan araştırma, Mayıs 2012 Ocak 2013 tarihleri arasında İstanbul'da üç Aile Sağlığ1 Merkezi, bir Üniversite Hastanesi ve bir Devlet Hastanesinde yürütüldü. İki tip kurumun seçilme nedeni, ülkemizde kronik hastalık yönetiminin birinci ve ikinci basamak sağlık kurumlarının sorumluluğunda olmasıdır. Araştırmanın örneklemini, en az 6 ay- dır. KOAH hastası olan, bir sağlık kurumundan hizmet alan, araştırmaya katılmaya engel oluşturacak fiziksel ve zihinsel engeli bulunmayan, 18 yaş ve üzerindeki hastalar arasından olasılıksız yöntemle seçilen 300 birey oluşturdu. Örneklemi oluşturan hastaların hizmet aldıkları sağlık kurumlarına göre temsil edilmelerini sağlamak için amaçlı olarak yarısı birinci basamaktan $(n=150)$ diğer yarısı ikinci basamak hizmet sunan $(\mathrm{n}=150)$ kurumlardan (hastanelerden) seçildi.

Veri Toplama Araçları: Veriler, Hasta Tanılama Formu ve Kronik Hastalık Bakımını Değerlendirme Ölçeği-Hasta Formu ile topland.

- Hasta Tanilama Formu: Hastaların sosyo demografik özellikleri (yaş, cinsiyet, medeni durum, eğitim, çalışma durumu), hastalık özellikleri (hastalık süresi, eşlik eden hastalık varlığı, son altı ayda acile başvurma ve hastanede yatma durumu, hastalığa ilişkin bilgi alma durumu, bilgi kaynakları), sağllk hizmeti aldıkları kurumlara (hizmet alınan kurum, hizmet alma süresi) ilişkin özellikleri kapsayan 13 sorudan oluşmaktadır.

- Kronik Hastalık Bakımını Değerlendirme ÖlçeğiHasta Formu (Türkçe PACIC): Wagner'in Kronik Bakım Modeline dayalı olarak Glasgow ve arkadaşları tarafından 2005 yılında geliştirilmiş olan ölçeğin, Türkçe geçerlik ve güvenirliği İncirkuş ve Nahcivan (2011) tarafından yapılmıştır. Likert tipte ve 20 maddelik ölçek, hasta katılımı, karar verme, amaç belirleme, problem çözme ve izlem/koordinasyon olmak üzere beş alt boyuttan oluşmaktadır. Ölçeğin puanlaması, "1=hiçbir zaman, 2=nadiren, 3=bazen, 4=çoğu zaman ve 5=her zaman" şeklindedir. Ölçek puanındaki artış, kronik hastalığı olan bireylerin aldıkları bakımdan memnuniyetlerinin yüksek ve kronik hastalık yönetiminin yeterli olduğunu gösterir. Ölçeğin Türkçe geçerlik ve güvenirlik çalışmasına göre; ölçeğin Cronbach Alfa katsayıs $\alpha=.91$, madde toplam puan korelasyonları $\mathrm{r}=.46$ ile .69 ( $\mathrm{p}=.001)$, dört-sekiz haftalık test-tekrar test korelasyonu oldukça yüksek bulunmuştur ( $\mathrm{r}=.93, \mathrm{p}=.001$ ) (İncirkuş ve Nahcivan, 2011). Bu çalışmadaki örneklem grubu için 
Cronbach Alfa katsayıs $\alpha=.80$ olup alt boyutlarda Cronbach Alfa değerleri; hasta katılımı 0.72; karar verme 0.62 ; amaç belirleme 0.43 ; problem çözme 0.31 ; izlem/koordinasyon 0.75 olarak bulundu.

Araştırmanın Değişkenleri: Bu araştırmada hastaların kronik bakım yönetimine ilişkin değerlendirmeleri memnuniyet puan ortalamaları olarak ölçülmüş olup toplam ölçek ve alt ölçek (hasta katılımı, karar verme, amaç belirleme, problem çözme ve izlem/koordinasyon) puan ortalamaları bağımlı değişkenlerdir. Kronik hastalık bakımı ile bağıntısı incelenen bağımsız değişkenler ise; yaş, cinsiyet, medeni durum, eğitim, çalışma durumu, hastalık süresi, eşlik eden hastalık varlığl, sağllk hizmeti alınan kurum, ayn kuruluştan hizmet alınan süre, son altı ayda acile başvurma ve hastanede yatma durumu, hastaliğa yönelik bilgi alma durumu ve bilgi kaynaklarıdır.

Verilerin Toplanması: Veriler bireylerin öz-bildirimine dayalı olarak yüz yüze görüşme yöntemi ile toplandı. Verilerin toplanmasında iki farklı yol izlendi. Hastanelerde bireyler Solunum Fonksiyon Testi laboratuvarlarına gelen hastalar arasından seçildi. Bu bölüme gelen KOAH'lı hastalardan araştırmaya katılmayı kabul edenler bekleme salonlarında uygun bir yere alındıktan sonra görüşme yapılarak veriler toplandı. Aile sağlı̆̆ merkezlerinde ise kayıtlı hastalar arasından belirlenen KOAH'lı hastalar telefonla aranarak araştırma kısaca anlatıldı, araştırmayı kabul edenler görüşme için aile sağlığı merkezlerine davet edildi. Bu merkezlerde veri toplama işlemi kurumun fiziki yapısına uygun olarak boş odalarda ya da bekleme salonlarında yapıldı. Veri toplama işlemi ortalama 20 dakika sürdü.

Etik Konular: Araştırma öncesinde ilgili kurumlardan kurum izinleri ve etik kurul izni (06.04.2012 tarih, 10055 sayılı izin) alındı. Araştırmaya katılan bireylere genel olarak çalışmanın amacı, veri toplama işleminin nasıl ve ne kadar süreceği vb. konularında açıklama yapıldıktan sonra çalışmaya katılmayı kabul eden bireylerden yazılı bilgilendirilmiş onam alındı. Okuryazar olmayan ya da imza atamayan/atmak istemeyen katılımcılardan ise sözlü onam alındı.
Araştırmanın Sınırlılıkları: Bu çalışmada, “örneklemin tüm KOAH'lı hastaları temsil etmeyip sadece belirli bir ilde, sınırlı sayıdaki sağlık kurumlarından hizmet alan KOAH'lı hastaları kapsaması; çalışmanın tasarım tipinin tanımlayıc1-kesitsel olması ve kullanılan veri toplama aracı Türkçe PACIC'in bazı alt ölçeklerinin cronbach alfa katsayısının bu örneklem grubunda düşük ve orta düzeyde bulunması" çalışmanın başlıca sinırlılıkları arasındadır.

Verilerin Değerlendirilmesi: Veriler bilgisayar ortaminda, Statistical Package for Social Sciences (SPSS 17.0) paket programı kullanılarak değerlendirildi. Tanımlayıc1 veriler "sayı, yüzde, ortalama, standart sapma ve medyan"; kronik bakım yönetimine ilişkin memnuniyet puan ortalamaları ile bağımsız değişkenlerin ilişkisi, "t-testi, ANOVA ve kolerasyon teknikleri” kullanılarak analiz edildi. Anlamlılık değeri $\mathrm{p}<0.05$ olarak kabul edildi.

\section{BULGULAR}

Çalışma kapsamına alınan KOAH hastalarının yaş ortalamas1 63.89 \pm 11.14 ' dür (min-max=38-87 yaş). Katılımcıların çoğunluğu erkek (\%70.3), evli (\%83) ve ilkokul mezunudur (\%41.7). Gelir getiren herhangi bir işte çalışanların oranı \%19'dur. Çalışmaya katılanların hastalık süresi 6 ay ile 35 yıl arasında (medyan 7.5 yıl) değişmekte olup, hastaların çoğunluğu (\%60.7) 5 yıl ve daha az süredir KOAH hastasıdır (Tablo 1).

Hastaların \%51.3'ü KOAH dışında başka kronik hastalıklara sahiptir. Bu hastalıklar en fazla oranda hipertansiyon (\%65), kalp hastalıkları (\%34) ve diyabet (\%25)'tir. Aile sağlığı merkezi ve hastanelerde izlemleri yapılan hastaların \%53.7'sinin izlem süresi 1-5 y1 arasındadır (medyan 5 yıl). Hastalığı nedeniyle, son altı ayda acile başvuranların oranı $\% 19$, hastaneye yatanların oranı \%5.3'tür. Hastaların \%49.3'ü hastalığıyla ilgili bilgi aldığını belirtmiş olup, bilgi kaynakla$\mathrm{r} 1$ arasinda en fazla oranda sirasiyla; doktor (\%85.8), televizyon/radyo (\%43.9) ve hemşire (\%23.6) yer almaktadır (Tablo 2). 
Tablo 1. Hastaların Bazı Sosyo-Demografik ve Hastalık Özellikleri ile Kronik Bakım Yönetimine İlişkin Memnuniyet Puan Ortalamalarının Karşılaştırılması $(\mathrm{N}=300)$

\begin{tabular}{|c|c|c|c|}
\hline Özellik & n (\%) & Ortalama \pm SD & İstatistik \\
\hline $\begin{array}{l}\text { Yaş } \\
40 \text { yaş ve altı } \\
41-64 \text { yaş } \\
65 \text { yaş ve üzeri }\end{array}$ & $\begin{array}{c}6(2.0) \\
151(50.3) \\
143(47.7)\end{array}$ & $\begin{array}{l}1.83 \pm 0.66 \\
1.72 \pm 0.38 \\
1.65 \pm 0.33\end{array}$ & $\begin{array}{c}F=1.77 \\
p=0.171\end{array}$ \\
\hline Yaş Ortalaması $(\mathrm{X} \pm \mathrm{SD})$ & $63.89 \pm 11.14$ & $\mathrm{r}=-0.24$ & $\mathrm{p}=0.094$ \\
\hline $\begin{array}{l}\text { Cinsiyet } \\
\text { Erkek } \\
\text { Kadın }\end{array}$ & $\begin{array}{c}211(70.3) \\
89(29.7)\end{array}$ & $\begin{array}{l}1.70 \pm 0.39 \\
1.66 \pm 0.31\end{array}$ & $\begin{array}{c}\mathrm{t}=0.87 \\
\mathrm{p}=0.383\end{array}$ \\
\hline $\begin{array}{l}\text { Medeni Durum } \\
\text { Evli } \\
\text { Bekar/Dul/Boşanmış }\end{array}$ & $\begin{array}{c}249(83.0) \\
51(17.0)\end{array}$ & $\begin{array}{l}1.70 \pm 0.38 \\
1.66 \pm 0.28\end{array}$ & $\begin{array}{l}\mathrm{t}=-0.58 \\
\mathrm{p}=0.563\end{array}$ \\
\hline $\begin{array}{l}\text { Eğitim } \\
\text { Eğitimsiz } \\
\text { Eğitimli }\end{array}$ & $\begin{array}{c}89(29.7) \\
211(80.3)\end{array}$ & $\begin{array}{l}1.58 \pm 0.26 \\
1.74 \pm 0.39\end{array}$ & $\begin{array}{c}\mathrm{t}=3.58 \\
\mathbf{p}=\mathbf{0 . 0 0 0}\end{array}$ \\
\hline $\begin{array}{l}\text { Çalışma Durumu } \\
\text { Çalışıyor } \\
\text { Çalışsmıyor }\end{array}$ & $\begin{array}{c}57(19.0) \\
243(81.0) \\
\end{array}$ & $\begin{array}{l}1.77 \pm 0.43 \\
1.67 \pm 0.35 \\
\end{array}$ & $\begin{array}{c}t=1.84 \\
p=0.066\end{array}$ \\
\hline $\begin{array}{l}\text { Hastalık Süresi } \\
5 \text { y1l ve altı } \\
6-10 \text { yil } \\
11 \text { yıl ve üzeri }\end{array}$ & $\begin{array}{l}182(60.7) \\
79(26.3) \\
39(13.0)\end{array}$ & $\begin{array}{l}1.68 \pm 0.35 \\
1.68 \pm 0.39 \\
1.77 \pm 0.39\end{array}$ & $\begin{array}{c}F=1.07 \\
p=0.344\end{array}$ \\
\hline Hastalık Süresi Ortalaması $(\mathrm{X} \pm \mathrm{SD})$ & $10.88 \pm 10.32$ & $\mathrm{r}=0.664$ & $\mathrm{p}=\mathbf{0 . 0 0 3}$ \\
\hline $\begin{array}{l}\text { Eşlik Eden Hastalık } \\
\text { Var } \\
\text { Yok }\end{array}$ & $\begin{array}{l}154(51.3) \\
146(48.7)\end{array}$ & $\begin{array}{l}1.71 \pm 0.37 \\
1.67 \pm 0.37\end{array}$ & $\begin{array}{c}t=1.04 \\
p=0.297\end{array}$ \\
\hline
\end{tabular}

Tablo 2. Hastaların Aldığı Sağlık Hizmeti Özellikleri ile Kronik Bakım Yönetimine İlişkin Memnuniyet Puan Ortalamalarının Karşılaştırılması $(\mathrm{N}=300)$

\begin{tabular}{|c|c|c|c|}
\hline Özellik & n (\%) & Ortalama \pm SD & İstatistik \\
\hline $\begin{array}{l}\text { Sağlık Hizmeti Alınan Kurum } \\
\text { ASM } \\
\text { Hastane }\end{array}$ & $\begin{array}{l}150(50.0) \\
150(50.0)\end{array}$ & $\begin{array}{l}1.63 \pm 0.27 \\
1.74 \pm 0.43\end{array}$ & $\begin{array}{c}\mathrm{t}=2.47 \\
\mathbf{p}=\mathbf{0 . 0 1 4}\end{array}$ \\
\hline $\begin{array}{l}\text { Sağlık Hizmeti Alınan Süre } \\
1 \text { y1ldan az } \\
1-5 \text { yıl } \\
6-10 \text { yıl } \\
11 \text { y1l ve üzeri }\end{array}$ & $\begin{array}{c}30(10.0) \\
161(53.7) \\
97(32.3) \\
12(4)\end{array}$ & $\begin{array}{l}1.68 \pm 0.45 \\
1.70 \pm 0.36 \\
1.65 \pm 0.35 \\
1.95 \pm 0.34\end{array}$ & $\begin{array}{l}F=2.60 \\
p=0.053\end{array}$ \\
\hline $\begin{array}{l}\text { Sağlık Hizmeti Alınan Süre Ortalaması } \\
(\mathrm{X} \pm \text { SD) }\end{array}$ & $8.50 \pm 7.91$ & $\mathrm{r}=0.41$ & $\mathrm{p}=0.111$ \\
\hline $\begin{array}{l}\text { Acile Başvurma Durumu } \\
\text { Evet } \\
\text { Hayir }\end{array}$ & $\begin{array}{c}57(19.0) \\
243(81.0)\end{array}$ & $\begin{array}{l}1.75 \pm 0.37 \\
1.68 \pm 0.36\end{array}$ & $\begin{array}{c}\mathrm{t}=1.32 \\
\mathrm{p}=0.189\end{array}$ \\
\hline $\begin{array}{l}\text { Hastanede Yatma Durumu } \\
\text { Evet } \\
\text { Hayır }\end{array}$ & $\begin{array}{c}16(5.3) \\
284(94.7)\end{array}$ & $\begin{array}{l}1.67 \pm 0.34 \\
1.69 \pm 0.37\end{array}$ & $\begin{array}{l}\mathrm{t}=-0.21 \\
\mathrm{p}=0.832\end{array}$ \\
\hline $\begin{array}{l}\text { Hastalığa İlişkin Bilgi Alma Durumu } \\
\text { Evet } \\
\text { Hayır }\end{array}$ & $\begin{array}{l}148(49.3) \\
152(50.7)\end{array}$ & $\begin{array}{l}1.82 \pm 0.40 \\
1.57 \pm 0.28\end{array}$ & $\begin{aligned} t & =6.20 \\
\mathbf{p} & =\mathbf{0 . 0 0 0}\end{aligned}$ \\
\hline
\end{tabular}


Çalışma kapsamındaki hastaların kronik hastalık bakım yönetimlerinden memnuniyet puan ortalamas1 toplam ölçek için $1.69 \pm 0.37$ 'dir. Alt ölçek madde puan ortalamaları sırasıyla, Hasta Katılımı için $1.86 \pm 0.72$, Karar Verme $2.34 \pm 0.63$, Amaç Belirleme $1.56 \pm 0.39$, Problem Çözme 1.81 \pm 0.51 , İzlem/Koordinasyon $1.24 \pm 0.50$ 'dir (Tablo 3 ).

Tablo 3. Kronik Hastalık Bakımını Değerlendirme Ölçeği'nin Madde Puan Ortalamaları (N=300)

\begin{tabular}{|l|c|c|}
\hline Ölçek ve Alt Ölçekler & $\begin{array}{c}\text { Madde Puan } \\
\text { Ortalaması } \\
\text { (min-max=1-5) }\end{array}$ & \pm SD \\
\hline Hasta Katılımı & 1.86 & 0.72 \\
\hline Karar Verme & 2.34 & 0.63 \\
\hline Amaç Belirleme & 1.56 & 0.39 \\
\hline Problem Çözme & 1.81 & 0.51 \\
\hline İzlem/Koordinasyon & 1.24 & 0.50 \\
\hline Toplam Ölçek Puanı & $\mathbf{1 . 6 9}$ & $\mathbf{0 . 3 7}$ \\
\hline
\end{tabular}

Hastaların ölçek maddelerine verdikleri yanıtların sayı ve yüzdelik dağılımları Tablo 4'te sunulmuştur. Buna göre hasta katılımı alt boyutunda, hastaların büyük çoğunluğu "Tedavi planım yapılırken görüşlerim alındı" (\%78), "Tedavim konusunda karar vermem için başka seçenekler sunuldu" (\%89) maddelerine hiçbir zaman; "Illaçlarım ve etkileri ile ilgili bir sorun olursa söylemem istendi" (\%51) maddesine bazen şeklinde yanıt vermişlerdir.

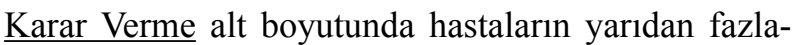
s1 "Sağlığım için yapmam gerekenler yazılı olarak verildi" (\%78), "Kendi bakımımı sağlamak için yaptığım şeylerin sağlığımı nasıl etkileyeceği açıklandı" (\%88) maddelerine hiçbir zaman; "Bakımımın iyi düzenlenmiş olmasından memnun kaldım" (\%61) maddesine çoğu zaman yanıtını vermişlerdir. Amaç Belirleme alt boyutunda hastaların büyük çoğunluğu "Kendi bakımımı yapma amacımın ne olduğu soruldu" (\%96), "Beslenme ya da egzersiz yapma davranışlarımı geliştirmem için yardım edildi" (\%88), "Tedavi planımın bir kopyası/örneği bana verildi" (\%86) ve "Hastall- ğımla baş etmemde bana destek olacak eğitimlere katılmaya teşvik edildim" (\%96) maddelerine hiçbir zaman; "Sağllk alışkanlıklarımla ilgili sorular soruldu" (\%62) maddesine ise bazen yanıtını vermişlerdir.

Problem Çözme alt boyutunda "Doktorum ya da hemşiremin gerekli olan tedaviyi önerirken değerlerimi, inançlarımı ve geleneklerimi dikkate aldıklarına eminim" maddesine hastaların yaklaşık yarısı (\%51) hiçbir zaman; \%30’u ise çoğu zaman yanıtını vermişlerdir. Hastaların büyük çoğunluğu “Günlük yaşamımda uygulayabileceğim bir tedavi planı yapmam için yardim edildi" (\%98) ve "Zor zamanlarımda bile kendime bakabilmem için yapmam gerekenler konusunda yardım edildi" (\%99) maddelerine hiçbir zaman yanıtını vermişlerdir. "Hastalığımın hayatımı nasıl etkilediği soruldu" maddesini ise hastaların \%56'si bazen, \%20'si çoğu zaman şeklinde yanıtlamışlardır. Beş maddenin bulunduğu İzlem/Koordinasyon boyutunda hastaların büyük çoğunluğu bütün maddelere hiçbir zaman yanıtını vermişlerdir. Bu maddeler sırasıyla, "Sağllk kontrollerim dışında da durumumu izlemek için bana ulaşıldı" (\%94); "Hastalığım konusunda bana yardımcı olabilecek sağglı programlarına katılmaya hiçbir zaman teşvik edildim" (\%94); "Diyetisye$n e$, eğitim hemşiresine ve ihtiyacım olan diğer sağlık uzmanlarına yönlendirildim" (\%86); "Diğer branşlardaki hekimlere gitmemin tedavime nasıl yardımcı olacă̆ı açılklandı" (\%84) ve "Diğer hekimlerle yaptığım görüşmeler konusunda sorular soruldu” (\%88).

Hastaların bazı sosyo-demografik özelliklerine göre kronik hastalık yönetimlerinden memnuniyet puan ortalamaları karşılaştırıldığında, yaş $(\mathrm{p}=0.171)$, cinsiyet ( $\mathrm{p}=0.383)$, medeni durum $(\mathrm{p}=0.563)$ ve çalışma durumuna ( $\mathrm{p}=0.066)$ göre puan ortalamaları yönünden anlamlı bir fark bulunmamıştır. Sosyo-demografik özelliklerden sadece eğitim ile ölçek madde puan ortalaması arasında anlamlı ilişki bulunmuştur $(\mathrm{p}=0.000)$. Eğitim durumu değişkeni çoklu karşılaştırma yerine ikili düzenlenerek analize alınmıştır. Buna göre ilkokul, ortaokul, lise, üniversite eğitimi olanlar birleştirilmiş, eğitimli ile eğitimsiz olarak karşılaştırılmıştır. 
Tablo 4. Ölçek Maddelerine Verilen Yanıtların Dağılımı

\begin{tabular}{|c|c|c|c|c|c|c|}
\hline \multicolumn{2}{|c|}{$\begin{array}{l}\text { Son } 6 \text { ay içinde kronik hastalığımla ilgili } \\
\text { bakım aldığımda ; }\end{array}$} & \multirow{2}{*}{$\begin{array}{c}\text { Hiçbir } \\
\text { Zaman } \\
\text { n (\%) } \\
235(78.3)\end{array}$} & \multirow{2}{*}{$\begin{array}{c}\text { Nadiren } \\
\text { n (\%) } \\
7(2.3)\end{array}$} & \multirow{2}{*}{$\begin{array}{r}\begin{array}{r}\text { Bazen } \\
\mathbf{n}(\%)\end{array} \\
45(15.0)\end{array}$} & \multirow{2}{*}{$\begin{array}{c}\text { Çoğu } \\
\text { Zaman } \\
\text { n (\%) } \\
12(4.0)\end{array}$} & \multirow{2}{*}{$\begin{array}{c}\text { Her } \\
\text { Zaman } \\
\text { n (\%) } \\
1(0.3)\end{array}$} \\
\hline \multirow{3}{*}{ 焉言 } & $\begin{array}{l}\text { 1. Tedavi planım yapılırken } \\
\text { görüşlerim alındı. }\end{array}$ & & & & & \\
\hline & $\begin{array}{l}\text { 2. Tedavim konusunda karar vermen } \\
\text { için başka seçenekler sunuldu }\end{array}$ & $267(89.0)$ & $2(0.7)$ & $27(9.0)$ & $4(1.3)$ & - \\
\hline & $\begin{array}{l}\text { 3. İlaçlarım ve etkileri ile ilgili bir } \\
\text { sorun olursa söylemem istendi. }\end{array}$ & $57(19.0)$ & $9(3.0)$ & $152(50.7)$ & $73(24.3)$ & $9(3.0)$ \\
\hline \multirow{3}{*}{ 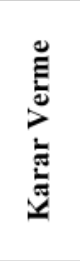 } & $\begin{array}{l}\text { 4. Sağlığım için yapmam gerekenler } \\
\text { yazılı olarak verildi. }\end{array}$ & $233(77.7)$ & $1(0.3)$ & $36(12.0)$ & $30(10.0)$ & - \\
\hline & $\begin{array}{l}\text { 5. Bakımımın iyi düzenlenmiş } \\
\text { olmasından memnun kaldım. }\end{array}$ & $1(0.3)$ & - & $29(9.7)$ & $184(61.3)$ & $86(28.7)$ \\
\hline & $\begin{array}{l}\text { 6. Kendi bakımımı sağlamak için } \\
\text { yaptığım şeylerin sağlığımı nasıl } \\
\text { etkileyeceği açıklandı. }\end{array}$ & $264(88.0)$ & $1(0.3)$ & $22(7.3)$ & $12(4.0)$ & $1(0.3)$ \\
\hline \multirow{5}{*}{ 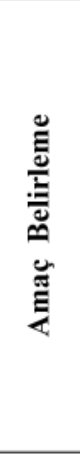 } & $\begin{array}{l}\text { 7. Kendi bakımımı yapma amacımın } \\
\text { ne olduğu soruldu. }\end{array}$ & $289(96.3)$ & $3(1.0)$ & $7(2.3)$ & $1(0.3)$ & - \\
\hline & $\begin{array}{l}\text { 8. Beslenme ya da egzersiz yapma } \\
\text { davranışlarımı geliştirmem için } \\
\text { yardım edildi. }\end{array}$ & $264(88.0)$ & $2(0.7)$ & $20(6.7)$ & $14(4.7)$ & - \\
\hline & $\begin{array}{l}\text { 9. Tedavi planımın bir kopyasılörneği } \\
\text { bana verildi. }\end{array}$ & $259(86.3)$ & $1(0.3)$ & $15(5.0)$ & $25(8.3)$ & - \\
\hline & $\begin{array}{l}\text { 10. Hastalığımla baş etmemde bana } \\
\text { destek olacak eğitimlere katılmaya } \\
\text { teşvik edildim. }\end{array}$ & $289(96.3)$ & - & $8(2.7)$ & $3(1.0)$ & - \\
\hline & $\begin{array}{l}\text { 11. Sağlık alıșkanlıklarımla ilgili } \\
\text { sorular soruldu. }\end{array}$ & $30(10.0)$ & $11(3.7)$ & $186(62.0)$ & $66(22.0)$ & $7(2.3)$ \\
\hline \multirow{4}{*}{ 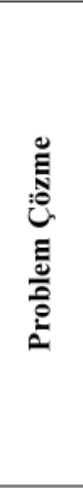 } & $\begin{array}{l}\text { 12. Doktorum ya da hemşiremin } \\
\text { gerekli olan tedaviyi önerirken } \\
\text { değerlerimi, inançlarımı ve } \\
\text { geleneklerimi dikkate aldıklarına } \\
\text { eminim. }\end{array}$ & $153(51.0)$ & $3(1.0)$ & $51(17.0)$ & $89(29.7)$ & $4(1.3)$ \\
\hline & $\begin{array}{l}\text { 13. Günlük yaşamımda } \\
\text { uygulayabileceğim bir tedavi planı } \\
\text { yapmam için yardım edildi. }\end{array}$ & $294(98.0)$ & - & $2(0.7)$ & $4(1.3)$ & - \\
\hline & $\begin{array}{l}\text { 14. Zor zamanlarımda bile kendime } \\
\text { bakabilmem için yapmam gerekenler } \\
\text { konusunda yardım edildi. }\end{array}$ & $296(98.7)$ & - & $2(0.7)$ & $2(0.7)$ & - \\
\hline & $\begin{array}{l}\text { 15. Hastalığımın hayatımı nasıl } \\
\text { etkilediği soruldu. }\end{array}$ & $50(16.7)$ & $16(5.3)$ & $167(55.7)$ & $61(20.3)$ & $6(2.0)$ \\
\hline \multirow{5}{*}{ 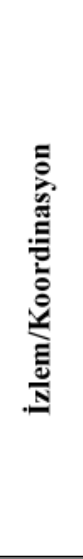 } & $\begin{array}{l}\text { 16. Sağlık kontrollerim dışında da } \\
\text { durumumu izlemek için bana ulaşıldı. }\end{array}$ & $281(93.7)$ & $4(1.3)$ & $14(4.7)$ & $1(0.3)$ & - \\
\hline & $\begin{array}{l}\text { 17. Hastalığım konusunda bana } \\
\text { yardımcı olabilecek sağlık } \\
\text { programlarına katılmaya teşvik } \\
\text { edildim. }\end{array}$ & $283(94.3)$ & $1(0.3)$ & $11(3.7)$ & $5(1.7)$ & - \\
\hline & $\begin{array}{l}\text { 18. Diyetisyene, eğitim hemşiresine ve } \\
\text { ihtiyacım olan diğer sağlık } \\
\text { uzmanlarına yönlendirildim. }\end{array}$ & $259(86.3)$ & - & $29(9.7)$ & $11(3.7)$ & $1(0.3)$ \\
\hline & $\begin{array}{l}\text { 19. Diğer branşlardaki hekimlere } \\
\text { gitmemin tedavime nasıl yardımcı } \\
\text { olacağı açıklandı. }\end{array}$ & $253(84.3)$ & $1(0.3)$ & $35(11.7)$ & $10(3.3)$ & $1(0.3)$ \\
\hline & $\begin{array}{l}\text { 20. Diğer hekimlerle yaptığım } \\
\text { görüşmeler konusunda sorular } \\
\text { soruldu. }\end{array}$ & $264(88.0)$ & $2(0.7)$ & $23(7.7)$ & $10(3.3)$ & $1(0.3)$ \\
\hline
\end{tabular}


Hastalık özelliklerine göre kronik hastalık bakım yönetimlerinden memnuniyet puan ortalamaları karşılaştırıldığında, hastalık süresi ile ölçek madde puan ortalaması arasında orta düzeyde ve pozitif korelasyon bulunmuştur $(r=.66, p=0.003)$. Hastalık süresi arttıkça kronik hastalık bakım yönetiminden memnuniyet de artmaktadır. Eşlik eden hastallk varlığı $(\mathrm{p}=0.297)$ ile kronik hastalık bakım değerlendirme puan ortalamaları arasında anlamlı fark bulunmamıştır (Tablo 1).

Sağlık hizmeti alınan kurumlara göre kronik hastalık bakımını değerlendirme ölçeği toplam puan ortalaması karşılaştırıldığında, hastalık izlemini hastanede yaptıranların ölçek madde puan ortalaması, Aile sağlığı merkezinden hizmet alanlara göre daha yüksek bulunmuş olup fark istatistiksel olarak ileri derecede anlamlıdır ( $\mathrm{p}=0.014)$. Sağllk hizmeti alınan süre hem yıllara göre hem de hizmet süresi ortalamasına göre memnuniyet puan ortalaması ile karşılaştırılmış ve farkın anlamlı olmadığı görülmüştür ( $\mathrm{p}=0.053$ ). Hastaların acile başvurma sıklığ $l(\mathrm{p}=0.189)$ ve hastanede yatma durumu $(\mathrm{p}=0.832)$ ile kronik hastalık bakım değerlendirme puan ortalamaları arasında anlamlı fark bulunmamıştır. Bireylerin hastalıklarına ilişkin bilgi alma durumu ile kronik hastalık bakımını değerlendirme ölçeği toplam puan ortalaması karşılaştırıldığında; bilgi alanların toplam puanlarının almayanlara göre anlam11 olarak yüksek olduğu bulunmuştur $(\mathrm{p}=0.000)$ (Tablo 2). Bilgi kaynaklarına göre incelendiğinde; doktordan $(p=0.034)$, hemşireden $(p=0.001)$ ve diğer kaynaklardan (akraba, arkadaş) $(\mathrm{p}=0.001)$ bilgi alma ile ölçek toplam puan ortalaması arasında anlamlı bir ilişki bulunurken, TV/radyodan ( $\mathrm{p}=0.743)$, dergi/broşürden $(p=0.739)$ ve internetten $(p=0.205)$ bilgi alanlarda anlamlı bir fark bulunmamıştır.

\section{TARTIŞMA}

KOAH'lı hastaların kronik hastalık yönetimlerini kendi bakış açılarından değerlendirerek bu konudaki sorunlu alanları belirlemek ve kronik hastalık yönetimi ile ilişkili olabilecek etmenleri incelemek amacıyla yapılan bu çalışmada, KOAH hastalarının bakım ve hastalık yönetimlerine ilişkin bazı önemli ipuçla- r1 elde edilmiştir. Büyük çoğunluğu erkek (\%73), 41 yaş üzeri (\%98) ve eğitimli (\%80) olan KOAH hastalarının, kronik hastalıklarına ilişkin aldıkları bakım hizmetlerinden memnuniyet puan ortalamaları olduk-

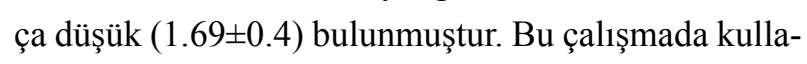
nılan ölçekteki değerlendirme ölçütlerine göre açıklamak gerekirse, hastalar kronik hastalık bakımına ilişkin hizmetlerin çoğunluğunun olması gerekeni karş1lamadığını belirtmişlerdir. Değerlendirmelerin çoğu "hiçbir zaman" ile "nadiren" arasında yer almıştır. Literatür bilgileri aynı ölçeğin farklı ülkelerde, fark11 kronik hastalıklarda da kullanıldığını göstermektedir. Amerika'da çeşitli kronik hastalığı olan bireylerde yapılan bir çalışmada, hastalıklara göre memnuniyet puan ortalamaları sirasiyla; diyabetli hastalarda $2.83 \pm 1.0$; depresyon hastalarında $2.71 \pm 1.1$; artrit-

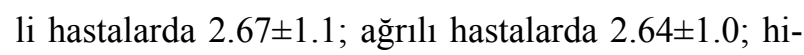
pertansiyon hastalarında $2.62 \pm 1.0$ ve astımlı hastalarda $2.40 \pm 1.0$ olarak bulunmuştur (Glasgow ve ark. 2005b). Almanya'da Rosemann ve ark. (2007) çeşitli kronik hastalığı olan bireyleri kapsayan çalışmasında, elde edilen memnuniyet puan ortalamaları diyabetli hastalarda en yüksek (2.73) olmak üzere diğer hastalarda sirasıyla koroner kalp hastalığı olanlarda 2.49; astım/KOAH hastalarında 2.44; hipertansiyon hastalarında 2.43 ve depresyon hastalarında 2.26 olduğu belirlenmiştir. Hollanda'da diyabetli ve KOAH'lı hastaları kapsayan bir çalışmada ise kronik bakım memnuniyeti diyabetli hastalara göre KOAH'lı hastalarda (2.3 \pm 0.8$)$ daha düşük bulunmuştur (Wensing ve ark. 2008). Değişik ülkelerde yapılan bu çalışmaların sonuçlarına benzer şekilde bizim çalışmamızda da KOAH'lı hastaların diğer hastalara göre aldıkları sağlik hizmetlerinden memnuniyetlerinin genel olarak daha düşük olduğu görülmektedir. Ancak karşılaşt1rılan bu çalışmaların çoğunun metodolojik çalışmalar olması nedeniyle KOAH'lı hastalardaki kronik bakım hizmetlerinden memnuniyet puan ortalamalarının düşük bulunma nedenleri çok açık değildir.

Hastaların toplam ölçek puanları düşük olmakla birlikte alt ölçek puan ortalamaları arasında farklı sonuçlar elde edilmiştir. Bu çalışma kapsamındaki hastala- 
rın alt ölçeklerden aldıkları puan ortalamaları en yüksekten düşüğe; karar verme, hasta katılımı, problem çözme, amaç belirleme ve izlem/koordinasyon şeklinde siralanmaktadır. Bu bulgular Rosemann ve ark. (2007) yapmış oldukları çalışmadaki alt ölçek sıralamaları ile benzerlik göstermektedir. Yanı sıra bizim çalışmamıza benzer şekilde Aragones ve ark. (2008), Glasgow ve ark. (2005b), İncirkuş (2010)'un çalışmalarında da karar verme alt ölçek puan ortalaması en yüksek, izlem/koordinasyon alt ölçek puan ortalaması en düşük bulunmuştur. Kronik Bakım Modeli’ne göre ölçeğin "hasta katılımı", "amaç belirleme" ve "problem çözme" alt boyutlarındaki ifadeler "öz-yönetim desteğine", "karar verme" alt boyutu ise "sağlik hizmetleri sunum planı" ve "karar verme desteğine" ilişkin hasta görüşlerini yansıtmaktadır. Bu nedenle çalışma kapsamındaki hastaların kronik bakım yönetiminden memnuniyetsizlikleri, sağlık kurumlarından aldıkları hizmetlerin organizasyonundaki yetersizliklerden ve hastalarda öz-yönetim desteğinin geliştirilememesine bağlı olabilir.

Karar Verme boyutunda yer alan üç madde sağlık hizmetlerinin planlanması ve bu planlamada hastanın karar verme sürecine katılımını yansıtmaktadır. Bu bağlamda hastaların çoğunluğu sağlıkları için yapmalarl gerekenlerin yazll olarak verilmediğini (\%78) ve kendi bakımlarını sağlamak için yaptıkları uygu-

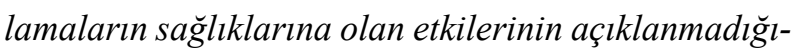
$n \iota(\% 88)$ ifade etmişlerdir. Bulgular KOAH'lı hastaların tedavi ve bakım süreçlerindeki kararlara katılımlarını sağlamada yetersizlikler olduğunu göstermekle birlikte, hastaların tamamına yakınının (\%90) bakımlarının iyi düzenlenmiş olmasından memnun kaldıklarını belirtmeleri, hastaların kronik hastalık izlemlerine yönelik sağlık sisteminde olması gereken düzenlemeler konusunda farkındalıkların yetersiz olduğunu göstermektedir.

Hasta katılımı boyutundaki maddelere de hastaların çoğunluğu karar verme boyutundaki maddelerle benzer şekilde, katılmadıklarını ifade etmişlerdir. Bu hastalar; tedavi planları yapılırken görüşlerinin alınma- dığını (\%78) ve tedavileri konusunda başka seçenekler sunulmadiğını $(\% 89)$ belirtmişlerdir. Sadece ilaç etki ve yan etkileri $(\% 78)$ konusunda hasta katılım1nın desteklendiği bulgulanmıştır. Bu durum diğer kronik hastalıklarda olduğu gibi KOAH'lı hastaların da büyük kısmının tedavi sürecine katılımlarının sadece ilaç kullanımı düzeyi ile sınırlı kaldığını düşündürmektedir. Oysa Kronik Bakım Modeli'nde de belirtildiği gibi yüksek kaliteli kronik hastalık bakımı, uygulama ekibi ve hasta arasındaki verimli etkileşim ile mümkündür. Bu etkileşimde hastanın kendi bakımında aktif ve bilgili bir katılımc1 olması beklenmektedir (Wagner ve ark. 2001).

Amaç Belirleme alt boyutunun temeli işbirlikçi amaçlar belirlemek için bilgi edinmektir. Bu boyuttaki puan düşüklüğü öz-yönetim eksikliğini gösterir (İncirkuş 2010). Bu bölümde hastaların yarıdan fazlası (\%62) sağlık alışkanlıkları ile ilgili kendilerine sorular yöneltildiğini ifade etmişlerdir. Buna karşın hastaların tamamına yakını kendi bakımını yapma amacına yönelik sorular sorulmadı̆̆ını (\%96), beslenme ve egzersiz konusunda yardım edilmediğini (\%88), hastalı̆̆lna yardımcı eğitim programlarına teşvik edilmediğini (\%96) ve düzenlenen tedavi planlarının bir kopyasının kendilerine verilmediğini (\%86) belirtmişlerdir. Wensing ve ark. (2008) çalışmalarında Amaç Belirleme alt boyut puan ortalamasının diğer alt boyut ortalamalarına göre daha düşük olması KOAH'lı hastalarda öz-yönetim eksikliği olduğunu vurgulamaktadır.

Kronik hastalık yönetiminin başarısında sağlık profesyonellerinin dikkate alması gereken diğer önemli bir etken ya da alt boyut problem çözmedir (Briggs 2003). Bu çalışmada hastaların yaklaşık yarısının (\%48), sağlık çalışanlarının inanç ve geleneklerini dikkate aldıklarını ifade etmeleri, bu örneklem grubuna hizmet veren sağlik profesyonellerinin toplumun inançlarına saygılı davrandığını düşündürmektedir. Buna karşın hastaların tamamına yakınının günlük yaşamlarında uygulayabilecekleri bir tedavi planı yapmaları için yardım edilmediğini (\%98) ve zor zamanlarında kendilerine bakabilmeleri için yapmaları ge- 
rekenler konusunda yardım edilmediğini (\%99) belirtmeleri, aynı sağlık profesyonellerinin hasta ile aralarında işbirliğine dayalı bir etkileşimin olmadığını göstermektedir. Hastaların tedavileri düzenlenirken inanç ve değerlerinin, sosyal ve kültürel koşullarının dikkate alınması halinde problem çözme alt boyutunun kriterleri yerine getirilmiş olacaktır.

Boult ve ark. (2008) çalışmalarında belirtildiği gibi, "hizmetlerin parçalı sunulması, sürekliliğin sağlanamaması, erişim güçlükleri ve koordinasyon eksikliği” kronik hastalık yönetimindeki önemli sorunlardan bazılarıdır. Yapılmış pek çok çalışmada (Aragones ve ark. 2008; Glasgow ve ark. 2005a; Glasgow ve ark. 2005b; İncirkuş 2010; Rosemann ve ark. 2007) olduğu gibi bizim çalışmamızda da İzlem/Koordinasyon alt boyutunun puan ortalamasının en düşük çıkması KOAH'lı hastaların yönetiminde özellikle izlem ve koordinasyonda ciddi eksikler olduğunu düşündürmektedir. Hastaların tamamına yakınının (\%94) să̆lık kontrolleri dışında durumunu izlemek için kendisine ulaşılmadı̆̆ını ifade etmesi bu kurumlarda hasta izleminin yeterli olmadığını; hastaların diğer sağllk profesyonellerine $(\% 86)$ ya da programlarina yönlendilmemeleri (\%94) de kurum içi/kurumlar arası koordinasyon eksikliğini ortaya koymaktadır.

$\mathrm{Bu}$ çalışmada aynı zamanda kronik hastalık yönetiminden hasta memnuniyeti ile bazı değişkenler arasındaki ilişkiler incelenmiş ve sadece "eğitim, hastalık süresi, sağlık hizmeti alınan kurum, hastalığa ilişkin bilgi alma durumu" ile anlamlı sonuçlar elde edilmiştir. Buna göre eğitimli olanların olmayanlara göre, hastalık izlemini hastaneden alanların ASM'lerden alanlara göre ve hastalığa ilişkin bilgi alanların almayanlara göre kendilerine sunulan sağlık hizmetlerinden memnuniyetleri anlamlı olarak daha yüksek bulunmuştur. Ayrıca bulgular hastalık süresi arttıkça hastaların aldıkları hizmetten memnuniyetlerinin de artt1ğını göstermiştir. Ancak hastalık süresinin hasta memnuniyetinde neden artışa yol açtığı tam anlaşılamamıştır. Bu konuda ileri araştırmalara gereksinim vardır. İkinci basamak sağlık kuruluşlarından hizmet alan
KOAH'lı hastaların kendilerine sunulan bakım hizmetlerinden memnuniyetlerinin daha yüksek olmas1, ASM'lerde KOAH hastalarının takip ve tedavilerinde eksik uygulamalar olduğunu ortaya koymaktadır. Ülkemizde diğer kronik hastalıklarda olduğu gibi KOAH'ın da ikinci basamakta tedavi edilmesi ve izlenmesi gereken bir hastalık olarak algılanması (Yaman ve Akdeniz 2010) nedeniyle bu durum beklenen bir bulgu olarak yorumlanmıştır.

Türkiye'nin de içinde bulunduğu 11 ülkeyi kapsayan KOAH'a ilişkin tutum ve inançları inceleyen geniş ölçekli uluslararası bir çalışmada hastaların tamamına yakını hastalıklarına ilişkin daha iyi bilgilendirmeye ihtiyaç duyduklarını belirtmişlerdir (Sayıner ve ark. 2012). Bizim çalışmamızdaki örneklem grubunda, hastalığına ilişkin bilgi alanların almayanlara göre kendilerine sunulan kronik hastalık bakım hizmetlerinden duydukları memnuniyetin daha yüksek olmas1, hastalığa ilişkin bilgi sahibi olmanın hasta memnuniyeti ile olumlu yönde ilişkili olduğunu destekler niteliktedir.

\section{SONUÇ VE ÖNERILER}

Hasta bakış açısından yapılan değerlendirmelere göre KOAH'lı hastalar, kendilerine sunulan kronik hastalık bakımından/yönetiminden memnun değillerdir. Hastaların kronik bakıma ilişkin memnuniyetlerini düşüren nedenler kurumsal olarak sağlık hizmetleri sunum plan1, karar verme desteği ve izlem/koordinasyondaki yetersizliklerden; hasta katılımı, amaç belirleme ve problem çözmeyi kapsayan, hastalardaki "öz-yönetim desteğinin” sağlanamamasından kaynaklanmaktadır. Kronik hastalık yönetiminden memnuniyet ile ilişkisi incelenen değişkenlerden sadece "eğitimli olma, hastalık süresinin artması, hastalık izlemini hastaneden alma ve hastalığa ilişkin bilgi alma durumu" anlam11 bulunmuştur. Bu çalışma sonuçları, kronik hastalık yönetiminde rolü olan sağlık profesyonellerinin mesleki yetkinlik ve hazırlıklı olmalarının yanı sıra sağlık sisteminde alt yapı düzenlemelerine de gereksinim olduğunu düşündürmektedir. Bu doğrultuda; 
- KOAH'lı hastaların memnuniyetlerini düşüren nedenleri dikkate alan hastalık yönetimi programlarının planlanması ve sağlık profesyonelleri tarafından kullanilmasi,

- KOAH'lı hastaların hastalıklarına yönelik hasta eğitimi/bilgilendirme programlarının yapılması,

- KOAH'lı hastalarda kronik hastalık yönetimini hasta bakış açısından değerlendirmek için daha geniş ölçekli ve ileri çalışmalar yapılması önerilir.

\section{KAYNAKLAR}

Adams, S., G. ve ark. (2007). Systematic review of the chronic care model in chronic obstructive pulmonary disease prevention and management. Arch Intern Med, 167: 551-561.

Aragones, A. ve ark. (2008). Validation of the Spanish translation of the patient assessment of chronic illness care (PACIC) survey. Preventing Chronic Disease, 5(4): 1-10.

Aşti, T., Kara, M. (2002). Kronik obstrüktif akciğer hastalığının evde bakım1. AÜTD, 34: 75-81.

Aydın, T. H., Yıldız, T. F., Karagözoğlu, Ş., Özden, D. (2012). Hastaların bakış açısıyla kronik obstrüktif akciğer hastalığı ile yaşamak: Fenomenolojik çalışma. İ.Ü.F.N. Hem. Derg., 20(3): 177-183.

Bodenheimer, T., Wagner, E. H., Grumbach, K. (2002). Improving primary care for patients with chronic illness: The chronic care model, Part 2. JAMA, 288(15): 1909-1914.

Boult, C., Karm, L., Groves, C. (2008). Improving chronic care: "Guided Care" model. The Permanente Journal, 12(1): 50-54.

Reduction of hospital utilization in patients with chronic obstructive pulmonary disease. Arch Intern Med,163(5): 585-591.

Bourbeau, J., Palen, J. van der (2009). Promoting effective selfmanagement programmes to improve COPD. European Respiratory Journal, 33(3): 461-463.

Briggs, H. A. (2003). Problem solving in diabetes self-management: A model of chronic illness self-management behavior. Annals of Behavioral Medicine, 25(3): 182-193.

Casas, A. ve ark. (2006). Integrated care prevents hospitalisations for exacerbations in COPD patients. European Respiratory Journal, 28: 123-130.

Escarrabill, J. (2009). Discharge planning and home care for endstage COPD patients. European Respiratory Journal, 34(2): 507512.

Fernandes, A., Pache, S., Bird, W., Bryden, C. (2006). Measures to improve knowledge of self-care among patients with COPD: A
UK general practice audit. Primary Care Respiratory Journal, 15: 307-309.

Global Initiative for Chronic Obstructive Lung Disease (GOLD) (2006). Global strategy for the diagnosis, management and prevention of chronic obstructive pulmonary disease, http://www.goldcopd.org/guidelines-global-strategy-fordiagnosis-management.html (21.05.2013).

Glasgow, R. E., Nelson, C. C., Whitesides, H., King, D. K. (2005a). Use of the patient assessment of chronic illness care (PACIC) with diabetic patients. Diabetes Care, 28: 2655-2661.

Glasgow, R. E. ve ark. (2005b). Development and validation of the patient assessment of chronic illness care (PACIC). Medical Care, 43(5): 436-444.

Haskett, T. (2006). Chronic illness management: Changing the system. Home Health Care Management Practice, 18: 492-494.

Hermiz,O., ve ark. (2002). Randomized controlled trial of home based care of patients with chronic obstructive pulmonary disease. British Medical Journal, 325: 938-942.

International Council of Nurses (ICN) (2010). International Nurses Day, Delivering Quality, Serving Communities: Nurses Leading Chronic Care. ICN - International Council of Nurses, Geneva, Switzerland.

İncirkuş, K. (2010). Kronik Hastalık Bakımını Değerlendirme Aracı'nın geçerlik ve güvenirliği. Yayınlanmamış Yüksek Lisans Tezi, İstanbul Üniversitesi Sağlık Bilimleri Enstitüsü, İstanbul.

İncirkuş, K., Nahcivan, N. (2011). Kronik Hastalık Bakımını Değerlendirme Ölçeği-Hasta Formu'nun Türkçe versiyonunun geçerlik ve güvenirliği. Dokuz Eylül Üniversitesi Hemşirelik Yüksekokulu Elektronik Dergisi, 4(1): 102-109.

Jonsdottir, H. (2008). Nursing care in the chronic phase of COPD: A call for innovative disciplinary research. Journal of Clinical Nursing, 17: 272-290.

Rosemann, T., Laux, M. D., Droesemeyer, S., Gensichen, J., Szecsenyi, J. (2007). Evaluation of a culturally adapted German version of the patient assessment of chronic illness care (PACIC) questionnaire in a sample of osteoarthritis patients. Journal of Evaluation in Clinical Practice, 13: 806-813.

Sayıner, A. ve ark. (2012). Attitudes and beliefs about COPD: Data from the BREATHE study. Respiratory Medicine, 106(S2): S60-S74.

Tatlıcıoğlu, T. (2007). Kronik obstrüktif akciğer hastalığı (KOAH) ve geleceği. Tüberküloz ve Toraks Dergisi, 55(3): 303-318.

Taylor, S. J. C. ve ark. (2005). Effectiveness of innovations in nurse led chronic disease management for patients with chronic obstructive pulmonary disease: Systematic review of evidence. BJM, 331(7515): 485. 
T.C. Sağlık Bakanlığı (2009). Temel Sağlık Hizmetleri Genel Müdürlüğü, "Türkiye Kronik Hava Yolu Hastalıklarını (AstımKOAH) Önleme ve Kontrol Programı (2009-2013) Eylem Planı", Anıl Matbaacılık, Ankara.

Ünsal, A.,Yetkin, A. (2005). Kronik obstrüktif akciğer hastalı̆̆ olan bireylerin günlük yaşam aktivitelerinin etkilenme durumunun incelenmesi. Atatürk Üniversitesi Hemşirelik Yüksekokulu Dergisi, 8(1): 42-53.

Ünüvar, N., Mollahaliloğlu, S.,Yardım, N. (Ed.) (2006). Türkiye Hastalık Yükü Çalışması 2004. Aydoğdu Ofset Matbaacılık San. ve Tic. Ltd. Şti., Ankara.

Wagner, E. H. ve ark. (2001). Improving chronic illness care: Translating evidence into action. Health Affairs, 20(6): 64-78.
Wensing, M., Lieshoud, J. V., Jung, H. P., Hermsen, J., Rosemann, T. (2008). The patient assessment chronic illness care (PACIC) questionnaire in the Netherlands: A validation study in rural general practice. BMC Health Services Research, 8: 182-188.

World Health Organization (WHO) (2012). Chronic Obstructive Pulmonary Disease (COPD), http//:www.who.int/mediacentre/ facrsheets/fs315/en/index.html (06.05.2013).

Yaman, H. ve Akdeniz, M. (2010). Kronik obstrüktif akciğer hastalığ $(\mathrm{KOAH})$ ve birinci basamakta tedavi rehberlerinin kullanımı. Sendrom Aktüel Tip Dergisi, 22(1): 17-20. 